\title{
Dealing with strategic tensions on the board: the role of the chair in fostering engagement and debate
}

Book or Report Section

Accepted Version

Morais, F., Kakabadse, A. and Kakabadse, N. (2019) Dealing with strategic tensions on the board: the role of the chair in fostering engagement and debate. In: Gabrielsson, J., Khlif, W. and Yamak, S. (eds.) Research Handbook on Boards of Directors. Edward Elgar, pp. 31-48. ISBN 9781786439741 Available at http://centaur.reading.ac.uk/81026/

It is advisable to refer to the publisher's version if you intend to cite from the work. See Guidance on citing.

Publisher: Edward Elgar

All outputs in CentAUR are protected by Intellectual Property Rights law, including copyright law. Copyright and IPR is retained by the creators or other copyright holders. Terms and conditions for use of this material are defined in 
the End User Agreement.

www.reading.ac.uk/centaur

\section{CentAUR}

Central Archive at the University of Reading

Reading's research outputs online 


\title{
CHAPTER
}

\section{Dealing with strategic tensions on the board: The role of the chair in fostering engagement and debate}

\author{
(C) Dr Filipe Morais \\ Post-doctoral Research Fellow \\ Governance, Leadership and Directorship \\ Henley Business School, Engine House, Room 506 \\ Henley-on-Thames, Oxon, RG9 3AU, UK \\ f.morais@henley.ac.uk \\ (C) Prof. Andrew Kakabadse \\ Professor of Governance and Leadership \\ Henley Business School, Engine House, Room 500 \\ Henley-on-Thames, Oxon, RG9 3AU, UK \\ a.kakakbadse@henely.ac.uk \\ (C) Prof. Nada K. Kakabadse \\ Professor of Policy, Governance and Ethics \\ Henley Business School, Engine House, Room 500 \\ Henley-on-Thames, Oxon, RG9 3AU, UK \\ n.kakabadse@henley.ac.uk
}

\begin{abstract}
This chapter presents the findings of a study of the chairs and CEOs of large UK listed companies, exploring the chair's role in harnessing the capabilities of the board in order to deal with strategic tensions. The study draws on 30 in-depth exploratory interviews with chairs and CEOs and finds that chairs have a wide range of choices at their disposal in pursuit of the surfacing and handling of strategic tensions by the board. These choices include setting the tone, the policy and practice of engagement between non-executives and the business, and between the board and the CEO. It is essential for the chair to take a proactive approach and ensure that tension-generating topics are part of the agenda and that all board members, formal or not, are encouraged to attend committee work. Engagement is insufficient if it is not followed by appropriate debate. Chairs manage board dynamics and participants' contributions during meetings, ensuring, by means of regular summarising and concluding, that tensions are confronted and discussed by all members and that a shared direction is agreed. Through such practice, chairs establish the degree of board involvement in strategy, aiming for an involvement that is both challenging and supportive of the executive and which is best described as interactive strategising. Boards of directors regularly face difficult, strategic-
\end{abstract}


tension-generating issues, and this study offers fresh insight into the chair's critical role as leader.

Keywords: Chairperson; Strategic Tensions; Board Engagement; Board Debate.

\section{Introduction}

The chairperson role is often described by regulators and academics alike as a non-executive one, charged with leading the board of directors in the pursuit of their legal and regulatory duties, as well as inducing good performance from the Chief Executive Officer (CEO) and the executive team. This, however, varies according to the country and corresponding regulatory environment. In the US Standard \& Poor's 500, for example, chairperson and CEO roles are held separate in 51 percent of companies, but only 28 percent of chairpersons are truly independent (Spencer Stuart, 2017a), whereas in the UK role separation has been embraced by about 99.3 percent of FTSE 350 companies (Spencer Stuart, 2017b). The old adage that a board is only as good as its next chairperson is in fact becoming increasingly more accurate, since the role has become greater in respect to both time and responsibility (Boyden, 2014). In fact, the "return of the chairman" has been heralded for quite some time now (Kakabadse and Kakabadse, 2007a). Recent studies in the US context indicate that the incumbent of the chair accounts for 9 percent of variation in firm performance, which exceeds the percentage attributed to the CEO, especially when environments are characterised by complexity and resource scarcity (Withers and Fitza, 2017). In this chapter complexity and resource scarcity is typical during recessions, financial crisis, or significant technology disruptions to the business model of the incumbent. It is the purpose of the chair to harness board members' diverse skills, experience and associations, and encourage challenging debate, all the while ensuring the board remains cohesive (Cadbury, 1992; Kakabadse and Kakabadse, 2007b; Taylor, 2001). However, in times of complexity and resource scarcity, the reality is that a number of strategic tensions will arise that can threaten the preservation of a collective and shared view of how the firm is managed and governed.

In this study, strategic tensions are broadly defined as firm-level competing demands that are handled at the highest levels of organisations and have strategic consequences for the organisation as a whole. Strategic tensions confront and are handled by top officers on a 
continual basis - this could be described as the essence of their role (Morais, Kakabadse and Kakabadse, 2018). From the board's perspective, strategic tensions threaten to disrupt the relationship between non-executives and executives and can cause rifts within the board. Strategic tensions may include, for example, divergences between board members around strategic direction, competitive advantage, or the relative balance between restructuring and growing the business (Morais, 2017). The role of the chair is hence critical in setting the tone for, and practice of, engagement, in maintaining a balance between challenging and supportive debate, and in ensuring the board as whole remains united around a shared strategy and vision.

This chapter draws on in-depth interviews with 30 chairs and CEOs of some of the largest UK listed companies, undertaken during a period in which the companies were undergoing restructuring, or experiencing a turnaround, reputational problems or other forms of corporate trauma - situations that disrupted governance and strategy arrangements and generated strategic tensions regarding the firm's future direction. The findings place the chair of the board in the critical seat in ensuring that strategic tensions are handled well through adequate engagement and effective board discussion practices.

The chapter is organised as follows. It starts with a brief review of the literature regarding the chairperson role in the UK context, followed by an outline of the study methodology. It then presents the findings derived from a thematic analysis of the interview material. The findings are illustrated with quotes and examples from study participants. The chapter closes with implications for the board's role as regards strategy, and a conclusion.

\section{The chairperson as leader of the board: a review of the literature}

The UK has a tradition of a one-tier unitary board composed of a mix of executives and a majority of non-executives, separate chairperson and CEO positions and mandatory audit, remuneration and nomination committees staffed with a majority or even a totality of nonexecutive, independent directors (Financial Reporting Council, 2016).

The UK Corporate Governance Code (Financial Reporting Council, 2016) emphasises the importance of the effective leadership of the board of directors by the chairperson. This is undertaken by ensuring that agenda items reflect the totality of non-executive director (NED) concerns, that time allocated to discussion is sufficient, and that management proposals are aired openly, sufficiently addressed and constructively challenged. It is also the chairperson's 
duty to ensure that NEDs receive adequate, independent and timely information both from internal and external sources that they are sufficiently engaged with the business, and that board members' induction, evaluation and development is carried out effectively (Financial Reporting Council, 2016).

A number of leadership studies have been undertaken to precisely determine the chairperson's role and to identify the leadership traits and competencies required (Kakabadse et al., 2001; Kakabadse and Kakabadse, 2008; Roberts, 2002). Some studies assert that effective boardroom dynamics can be achieved through chairpersons' social and political skills in managing often sensitive relationships and individual egos, and by their being able to mitigate and avoid interpersonal collision in a complex and subtle way (Kakabadse et al., 2001). Ultimately, the chairperson's job is to manage processes of accountability (Roberts, 2002; Roberts, McNulty and Stiles, 2005), described as "processes of learning, which acknowledge the inevitable incompleteness of individual thought, and through which strategy emerges as the synergistic outcome of board discussion" (Roberts, 2002:515). The chairperson needs to create "positive dynamics of accountability" by supporting a culture of challenge and support, setting the behavioural standards expected and managing the agenda and information flows in ways that facilitate NED involvement and contribution while retaining independence of mind. Hence, the chairperson plays an important role in ensuring quality of debate so that "the interplay of different skills and perspectives amongst different members of the board can itself produce new perspectives that offer creative solutions to particular dilemmas" (Roberts, McNulty and Stiles, 2005:S16).

Recognising the importance of board leadership, Kakabadse et al. (2001) conducted one of the first in-depth interview studies of UK FTSE 100 company directors. It was found that a high-performing chairperson exhibited maturity, relational skills, high political and social competence, meetings skills and coaching capabilities, all of use in managing boardroom dynamics, with boardroom politics and social dimensions being key. Leblanc and Gillies (2005) go as far as to view the leadership qualities of the chair (and its relationship with the CEO) as the single most important factor impacting board effectiveness. It has been proposed that the three most important tasks of the chairperson are i) assessment of, and relationship with, the CEO; ii) preventing board denial; and iii) dealing with non-performing directors (Leblanc and Gillies, 2005).

Other research shows that the chair plays an essential role in reconciling conflicting agendas. Acknowledging and valuing differences, yet finding underlying complementarities, common views and causes, is at the heart of chairperson leadership as well as boardroom 
effectiveness (e.g. Dulewicz, Gay and Taylor, 2007; Kakabadse and Kakabadse, 2007b; Kakabadse, Kakabadse and Knyght, 2010; Roberts, 2002). Other studies, such as the one by Kakabadse and Kakabadse (2008), identify six disciplines that a world-class chairperson needs to master in order to lead for boardroom effectiveness: i) delineating boundaries (between chairperson and CEO roles, distinct from board and management roles); ii) sense-making (concerning the mission, vision and values in the boardroom and the organisation); iii) interrogating the argument (questioning policy and strategy); iv) influencing outcomes (through building shared objectives and alignment); v) living the values (based on trust and integrity and paying attention to the imbalances between espoused values and practised values); and vi) developing the board (which includes board evaluation, selection, development, coaching, etc.) (Kakabadse and Kakabadse, 2008). Yet chairpersons' leadership behaviours and styles vary according to board and corporate context. For example, Levrau and Van den Berghe (2013) interviewed company secretaries from 39 large companies in the Belgium Stock Exchange large-capitalisation (BEL 20) and medium-capitalisation companies (BEL MID) (33 of which had separate chairperson and CEO roles), and found that chairpersons exhibited highly heterogeneous leadership styles which impacted on the quality of the decisions made and on the group's commitment to those decisions. It is argued that the chairperson should be able to transform the boardroom into an effective collective decision-making body, by removing "negative group dynamics" (Levrau and Van den Berghe, 2013). This requires a chairperson to have particular specific personal competencies and attributes that go beyond the structural aspects of board leadership, and which include creativity, criticality, preparedness and commitment (Levrau and Van den Berghe, 2013).

There is a growing stream of literature focusing on the chairperson's role, skills and contribution (Dulewicz, Gay and Taylor, 2007; Kakabadse and Kakabadse, 2008; Levrau and van den Berghe, 2013), and viewing the relationship between the chair and CEO (Kakabadse, Kakabadse and Barratt, 2006; Kakabadse, Kakabadse and Knyght, 2010; Roberts, 2002) as central to board effectiveness. This literature converges on the idea that the chairperson is a "bridge", playing a role in balancing different interests, skills and perspectives inside and around the boardroom: the crucial person who is charged with transforming the board into an effective collective decision-making group (Levrau and Van den Berghe, 2013) or a highperforming team (Gabrielson, Huse and Minichilli, 2007). Strategic tensions are likely to emerge from the confrontation of these different interests, skills and perspectives, especially in uncertain, complex and resource-constrained environments; but how the chairperson systematically handles strategic tensions remains relatively under-explored. 


\section{The study}

The findings and insights contained in this chapter have emerged from a thematic analysis of 30 in-depth interviews with highly experienced chairs and CEOs of UK large listed companies, across 18 sectors. The number of individuals per sector is shown in the table 1, below.

Table 1: Sample by industry

\begin{tabular}{|l|c|}
\hline Sectors & Interviews \\
\hline Manufacturing & 4 \\
\hline Retail & 3 \\
\hline Printing \& publishing & 3 \\
\hline Travel \& leisure & 3 \\
\hline Oil \& gas & 2 \\
\hline High-tech & 2 \\
\hline Construction & 2 \\
\hline Broadcasting & 2 \\
\hline Pharma & 1 \\
\hline Telecom & 1 \\
\hline Infrastructure & 1 \\
\hline Defense \& aerospace & 1 \\
\hline Energy & 1 \\
\hline Entertainment & 1 \\
\hline Banking & 1 \\
\hline Insurance & 1 \\
\hline Consulting & 1 \\
\hline Total & $\mathbf{3 0}$ \\
\hline
\end{tabular}


In total, 14 chairpersons and 16 CEOs were interviewed. There were 27 individuals from a White British background and three from "Other White" background; 29 were male and one female. The lack of female representation partly reflects the gender imbalance particularly noticeable in FTSE 100 top positions. In 2014-15, when the study was carried out, there were only three female chairs and five female CEOs in the FTSE 100 (Davies, 2015). The average age was 58, with chairpersons being, on average, older (61.7 years) than CEOs (56 years). Interviews were conducted in London between July 2014 and October 2015. Participants were initially selected via a consultancy firm based in London and there was an element of THE snowballing technique used for sampling. The criteria for selecting initial participants is based on them having significant experience as CEO and/or chairperson of FTSE100 companies during periods of significant complexity and resource scarcity (i.e. recessions, financial crisis, technology shifts disrupting the business). Despite having reached data saturation by the $20^{\text {th }}$ interview (i.e. the point at which no new data emerges that modifies existing categories) (Francis et. al., 2010), we continued with a further 10 interviews to strengthen the results as well as to benefit from the unique access to FTSE board directors.

The participants were asked to discuss the role that chairpersons play during periods of significant disruption to the company (i.e. companies in turnaround and restructuring mode, or facing a severe reputational problem), where strategic tensions were likely to surface and require handling by the chair of the board.

This exploratory and inductive study (Saunders, Lewis and Thornhill, 2009) aimed to investigate how chairpersons respond to strategic tensions and to understand the demands, constraints and choices that chairs face in such situations. The interview material was separated by role type (CEO and chair), and further delineated according to how respondents evaluated the role of the chair and how effectively, according to the respondent, strategic tensions in the boardroom were handled by the chair. The analysis followed an inductive logic where interview material was coded to progressively form higher-level codes which were aggregated into themes and sub-themes (Braun and Clarke, 2006; Patton, 2002). The thematic analysis included six broad phases: i) immersion in the data (including transcribing, and reading verbatim); ii) generating initial coding; iii) searching for themes (i.e. how different codes combine to form a theme); iv) refining the themes (ensuring consistency within and across themes); v) defining and naming the themes; and vi) producing an analytical report of the analysis (Braun and Clarke, 2006).

To provide consistency within the coding procedure across the interviews, as well as to allow comparability, the authors used the Demands-Constraints-Choices (DCC) theory of role 
(Stewart, 1982, 1991) which provided a framework from which to depart as well as code for the chairperson role. The DCC model posits that managers' available choices or opportunities within the role are dynamically influenced by role demands (i.e. what is expected of any incumbent in terms of task and output in order to stay in the job) and internal and external constraints, which can be personal (e.g. own preferences) or organisational (e.g. reward systems, training), or they can be of physical (e.g. resources) or social and cultural natures (e.g. legal norms, peer attitudes, leadership) (Stewart, 1982, 2003). The nature of demands and constraints is situational, so the available behavioural choices adapt accordingly (Stewart, 2003). Choices are enacted in three domains: i) aspects of the role to which the incumbent chooses to devote more time and commitment of resources; ii) the tasks that are delegated; iii) boundary management (Stewart, 1982). The DCC model is consistent with observations by Hales (1986), as it allows for variation and contingency, choice and negotiation, pressure and conflict, and reaction and non-reflection, stressing that managerial (and directors') activities "may be competing, even contradictory" (Hales, 1986:102). What is more, role theory, and particularly the work of Rosemary Stewart, has been widely recognised for its contribution to qualitative methodologies (Parry, 2003), often seen as "exemplars of the argument for qualitative reasoning rather than quantitative analysis for studying a complex and weakly understood phenomena" (Kroeck, 2003:204). The use of this model for qualitative inquiry has been successfully used in past similar studies (e.g. Kakabadse and Kakabadse, 2007a; Morais, Kakabadse and Kakabadse, 2018; Stewart, 1991). The next section presents the findings of the study.

\section{Study findings}

The analysis of the role of the chair in handling strategic tensions in the boardroom has shown that high-performing chairs ensure that strategic tensions are proactively surfaced and handled through appropriate engagement and debate. Two key themes emerged as critical chair practices in support of the effective handling of strategic tensions: i) Establishing and developing both a policy and practice of board engagement; and ii) Managing board debate, dynamics and contributions on tension-generating topics. These themes are broken down into a number of sub-themes which are explored and discussed in the rest of the chapter. 


\subsection{Establishing and developing both a policy and practice of board engagement}

A key demand of the chairperson role is to ensure an adequate level of board engagement with the business and with the CEO. Such practice lays the foundation for effective surfacing and handling of strategic tensions within the boardroom. This theme includes a variety of practices, namely: i) setting the expectations and practices of NED engagement with the business by requiring them to visit operations, talk to people at different levels within the company and attend specific events; ii) setting the tone for CEO-board engagement by establishing a process where potentially controversial strategic issues are discussed well in advance of a decision being required, and hence establishing a culture of supportive engagement between the board and $\mathrm{CEO}$; and iii) setting the board agenda and working for engagement; this entails getting tension-generating topics onto the agenda and managing committee work and information flows.

\subsubsection{Non-executive directors' engagement with the business}

Chairpersons have responsibility for imposing and encouraging the level of NED engagement. High NED engagement is perceived by chairpersons as an indication of NEDs' knowledge of the company and its challenges, and hence renders them better equipped to discharge their duties of challenging and advising management. One chairperson explained his approach:

... and the board members have total carte blanche to go wherever they like in the company. They can go into executive meetings, $R \& D$ research, product marketing, the management meeting that the CEO chairs, visit any research establishment, any manufacturing or commercial unit, find out what's going on, ask questions, be better informed and hopefully more able to add value when it came to looking at the issues and challenges. No chaperoning - and initially I said, "Go and be a fly on the wall, but if you need to ask a question, ask a question", and that is now part of the way the company operates. And I always had that right, if you like, but I wanted to make sure all my board members did. (Chairperson 3)

The chairperson of a large retailer explained his approach of ensuring that non-executive board members are close to the business and connected with the business reality:

We actually have quite a few breakfasts where non-executives come in here and talk to people of all levels in the business, because we really want people to understand what the board does. And I think it always surprises people in the business how in touch the board is with day-to-day life here, because normally you would think this is some remote thing that you never see. But actually I think almost all of our non-execs have been in and done these employee breakfasts and I think 
that's really valuable. And I do a number of them as well and they can get a sense of "should I trust these people to both hold to account and challenge?" but also encourage the executive team, because I think they expect that from a board. (Chairperson 4)

Studies in UK and US contexts have identified that effective chairpersons ensure that these engagement practices are part of their board culture. Facilitating NEDs' independent access to sources of information (e.g. by visiting operations, directing questions to lower levels of management, and accessing company documents) has been identified as an effective chairperson practice contributing to NED role fulfilment as regards monitoring and advising management (Carter and Lorsch, 2004; McCabe and Nowak, 2008; Pettigrew and McNulty, 1995; Roberts, McNulty and Stiles, 2005).

It is therefore down to the chairperson to set the tone and expectations of NED engagement and contribution (Roberts, McNulty and Stiles, 2005), enabling NEDs to gain access to unfiltered direct information from different business units, employees, customers and other stakeholders. This allows NEDs to move away from a management-feeding process and be more effective in challenging and advising management. In this way, strategic tensions are likely to be surfaced in a more informed manner by providing NEDs with independent and firm-specific knowledge, useful in fully exposing and debating strategic tensions with the executive.

\subsubsection{Board-CEO engagement}

Board-CEO engagement is another important aspect for the chairperson to manage. As noted by several researchers, strong and engaged boards are an indicator of effective chairpersonship (e.g. Bailey and Peck, 2013; Leblanc and Gillies, 2005). Regarding board-CEO engagement, two aspects are salient in this study: i) the need to engage with the board in a timely manner regarding tension-generating topics; and ii) supportive engagement between the board and the CEO.

\subsubsection{Timely board engagement with strategic-tension-generating topics}

Non-executive board members can be frustrated and disengaged if they feel that they are being forced into taking a decision about a topic that is complex or even contentious. 
The chairperson of a large pharmaceutical company explained how he implemented a change in CEO-board interaction. Topics that were a source of tension were raised in good time with the board, allowing the board to understand and explore them with the CEO before problems materialised or major commitments were made. This in turn demanded greater engagement with the business challenges by board members.

... I wanted to change the way the board and management interacted. So that meant that what I wanted from the CEO was that he would bring ideas to the board at an early stage of development, recognising that some of them would be half-baked and jumped, but giving the opportunity for the board to interact at an early stage and understand therefore what he was trying to achieve ... That then placed a demand on the board to be much more engaged than they had been, so they understood more deeply the issues and challenges that the company had. So we evolved, both he raising subjects early on that concerned him; sometimes they were late because it was an emerging risk that suddenly hit us. (Chairperson 3)

Another chairperson from a large tobacco company reported a similar practice in CEOboard interaction. In this industry, the disruptive potential of e-cigarettes is a constant presence. Interaction allows the continual exploration of the company's position in the face of this emergent threat.

... off the top of my head, probably six or seven briefing papers over a year or two years, 18 months probably, and the board is fully engaged. But much more engaged from an education point of view: "Do you guys think we're sort of going down the right track?" But, no, the board, no, very focused - important issue. (Chairperson 4)

Another chairperson explained his role in ensuring that the CEO and the board discuss tension-generating topics early and continuously.

... my role here would be kind of to ensure that the board was completely informed and involved in these huge changes, right through, not just one-off, but steadily and continuously. (Chairperson 2)

CEOs expressed similar views about CEO-board interaction, that is: in raising potentially tension-generating topics early with the board, so that engagement built slowly, directors became increasingly aware of the tensions and gained trust in the way the CEO was addressing them. If such tensions become salient and materialise as issues, the board is in a comfortable position to support the executive.

... quite often we'll produce for the board what looks like a board paper, what looks like an authorisation paper - but isn't - and essentially it goes to the board 
with a condition that there will be no decision taken, but it gives everybody a safe environment to explore how they feel about this option. Now, the deal is: you can't criticise us, so the risk of that is that you could say, "Well, look, you've taken five ideas to get what you want. One said turn right, one said turn left, one said go forward. And you didn't do any of them. Do you know what you're doing?" Right that's - which is where I think some people could lack. My view is the only way to really give the board a clear view of where the solution space is, is to be able to explore the solution space ... the value of the board is at its maximum when the option is being initially considered, and it diminishes as it becomes more crystallised. And the reason for that is: because in a company this size you'd expect a lot of the details to be, you would not expect a useless proposal when you've got a company of this size. (CEO 7)

Time and again, CEOs explained how ensuring boards' early and continuous engagement with strategic topics allows confidence, awareness and understanding to grow, so that, when and if a decision is required, there is a history of interaction and thinking on the topic. This engagement process allows the CEO to understand each individual director's views and preferences, and shape the proposals to accommodate these views, before submitting to the board for a decision.

We're always engaging with topics. So what we tend to do is: we will put a topic into the board to get a discussion round about it, to get their views and input, so as we essentially shape things before we get to the decision. Because what I don't like is: I do not like forcing people to have to make a decision. Because I don't want people to be uncomfortable ... (CEO 9)

Some CEOs described the relationship with the board as transparent and open (i.e. any issues can be debated), and indicated the importance of having opportunities to meet informally outside normal board meetings, which provide the right context for good debate and discussion of important issues.

... we have a horribly transparent relationship; there are very few things that the board doesn't know. We deliberately have two mechanisms of the board which work extremely well. So the dinner, the board dinner, which very often will be me on my own with the non-executives, we're entirely free-flowing and strategic: What's happening? What do we think about the environment? What do we think other companies are, so where are the big scary issues? So they'll be regularly, and very often there will be over a period of two or three years, the same subject might be covered in $70 \%$ of those meetings, not super detail. (CEO 7)

Chairpersons and CEOs both indicated that successful board-CEO engagement needs to be based on strategic topics - threats and opportunities - in a climate of openness and transparency that allows difficult issues to be discussed. This is often facilitated by means of 
informal dinners and engagement outside the traditional, formal and minuted board meetings. Engagement is depicted as an ongoing process in which strategic topics are raised early (and sometimes stay on the agenda for years) so that the views of individual board members are heard before the CEO makes too strong a commitment to a course of action. This allows directors to gain trust about how strategic tensions are being addressed and gives them a continuous feed about how executive thinking is evolving.

\subsubsection{Supportive board-CEO engagement}

Ongoing board engagement regarding strategic business challenges allows continuous alignment to be built between the board and the CEO. Such alignment ensures there are no surprises for the board when strategic challenges require action. Because the board has been continuously engaged with the topics, and a shared understanding of the issues has been built up gradually, trust has developed and the board more readily engages with the necessary decisions in a supportive manner. CEOs in this study all agree that, when engagement with strategic topics happens openly and progressively in the manner described above, the board is more likely to show support for decisions when they become due.

... it's about taking them on board, it's about involving them, it's making them feel they're part of the decision-making. It's about - and this is where boards in total, i.e. non-execs and executives, if they work together, can be very unified and very strong and all speaking off the same song sheet. (CEO 11)

Two further CEOs explained how they felt total unity and alignment between the board and the executives when the time came to make difficult decisions about ongoing strategic tensions.

... in the world of trying to deal with a myriad of complex issues and stakeholders with the board 100\% behind you, I knew I could rely on them. You couldn't get a cigarette paper between the executive and the board, so as we went to the outside world we were unanimous. (CEO 2)

... they trusted what we were saying ... that's where a board moves, in my humble opinion, from being one which is construed as an unnatural work team by the essence of what governance says: it's where you want them then to coalesce, when you have a problem, to be a natural work team ... it's really important the board takes that same approach, which says: so you've got to have unity; which says: we were supportive of the executive doing this, the whole board was supportive of it, because quite often we get "where was the board?" and you say the board was absolutely 100\% behind us. (CEO 10) 
When engagement happens in this way, it reduces the time needed to respond to strategic issues that require immediate action.

... it was a conversation with my executive colleagues, and obviously the board were heavily involved in this. They were, obviously, they could see what was happening. We were keeping them very informed on it. [The board was] interested in we were taking action, the necessary action, as fast as we could, and then it was about reporting back to them the progress that we were making. (CEO 1)

Chairpersons have overall responsibility for ensuring adequate level and quality of engagement between the board and the CEO. It is for the chairperson to set expectations about engagement and how the board is to interact with the CEO. Obviously, engagement is a twoway process and the CEO needs to play his or her part in keeping the board informed and engaged. In addition to setting the tone for board-CEO engagement, the chairperson has the additional responsibility of determining and organising the board agenda and working in such a manner that quality of engagement is achieved and strategic tensions are discussed appropriately. This is discussed next.

\subsubsection{Organising the board agenda and working for engagement}

Chairpersons have a lot of options available to them in shaping board agendas and ensuring appropriate board engagement with tension-generating topics. Setting the board agenda, and avoiding CEO domination of this process, has been consistently cited in research as an important chairperson responsibility (Bailey and Peck, 2013; McNulty et al., 2011; Pettigrew and McNulty, 1995; Roberts, McNulty and Stiles, 2005). In this study, the chairperson of a large tobacco company explained how the threat of e-cigarettes as a substitute for the company's product is a recurring issue on the board agenda.

E-cigarettes exactly the same [i.e. regular item on the board agenda]. We're very conscious that it could be very disruptive, or people talk about it as the Kodak moment potentially for tobacco. We don't think so now, but we are alert to it and we think that we have enough rigour into the process to work out at what point it flips that we can be genuinely fast followers. (Chairperson 5)

Another chairperson was decisive when asked about his role in dealing with strategic tensions. In a business facing technology disruption, which requires a transition to a new business model based on digital technology, the chairperson highlighted his role in ensuring that the tensions between legacy business and new business get onto the board agenda and are 
challenged vigorously.

My one job which I can do as a chairman is get these issues on the table: like the legacy issue, it's really useful. I've got a good board who care, they're engaged, they challenge, but it's not this niggling kind of challenge that they teach people on strategy courses: some nonsense, babbling on like this. I just want to say, "Come on, give me something substantive. Let's get into the business. Don't sit there and try to be cute by asking piddling questions." (Chairperson 2)

Chairpersons respond to strategic tensions by getting them onto the board agenda and ensuring robust discussions that lead to a continuous common understanding of the tensions and the company's strategic direction. This means board members confront the tensions on an ongoing basis and continuously monitor and calibrate executive thinking and strategic proposals.

How the board functions, however, may need re-evaluating as circumstances change. One chairperson explained how he increased the number of meetings as well as the level of information brought before the board during the 2008-2009 financial crisis:

Our normal board cycle, they meet every year and, I forget, it was 2008, 2009, we had 30 meetings one year and just about the same the next year. And that had two effects. One is: it denied the opportunity of saying, "Well, you, you've moved into a place where I wouldn't be happy with", but, secondly, it actually had the opposite effect, is they felt that they could, because it wasn't just, there was, "Here's the latest", it was "Here's the problem: what, how are we going to solve it?" They were deeply involved, and I absolutely reached out to each and every one of them to do that. And some were better than others at coping with that, but they, no one could say there weren't given a chance to say their bit ... (Chairperson 9)

Chairpersons have freedom of choice in organising board work and the frequency of board meetings, and also in defining priority areas. It is also up to the chairperson to make changes to the board's function that reflect changes in business circumstances.

Chairpersons are also free to decide when special subcommittees are required in order to address non-programmed issues, as well as deciding who sits on committees and subcommittees. Since Cadbury (1992), audit, remuneration and nomination committees have been progressively adopted and are now established in the vast majority of FTSE publicly listed companies. Such committees, it is argued, constitute strategic tools to increase external legitimacy and ensure specialised monitoring and control of executive action (Harrison, 1987). Other studies have shown that NEDs working simultaneously in remuneration and audit committees might find it hard to reconcile a strategy and monitoring function (Spira and Bender, 2004). Less discussed in the literature is the impact of board committees and 
subcommittees on information flows and overall NED engagement. In this study, chairpersons see committee work as necessary for addressing particular emerging topics of concern, but they also see committees and subcommittees as dangerous, as they can exclude some board members from important decisions, and place them at an informational disadvantage, thereby breaking down engagement. One chairperson explained:

There'll be a subcommittee. We always form them when there's something big going on. For example, $M \& A s$ : we will always run a subset of the board and I will always make sure that the skills I want are there. I tell those people they've got to just free up their diaries, and I will speak to them if they are having problems. And we do meetings late at night and we do meetings on Sundays. And so we've got that added flexibility: mandatory they attend. But the rest of the board is always informed when we're having a subcommittee meeting and they are all invited to attend, but they're not mandatory attendees. (Chairperson 5)

This concern about the potential for committees and subcommittees to break information flows and engagement was expressed several times:

... even though we have committees, everybody is free to join every committee and, yeah, as a matter of fact, everybody joins every committee. So they are not a full voting member but everybody is, and so there is not a two speed or two level of intelligence - particularly dangerous in my mind when it comes to audit that the audit people know so much more than the non-audit members. So all board members were continuously on the same level of information. (Chairperson 8)

Such concerns echo Sharpe (2012), who warns that increased formalisation of the structure and complexity of boards may have unintended effects on the processing of information for good decision-making. To ensure that committees and subcommittees are not a constraining factor, some chairpersons choose to have an open policy where every board member is invited to sit on committees and subcommittees, thereby enabling an equal level of information and engagement of non-executives on important business topics.

\subsection{Managing board debate, dynamics and contribution on tension-generating topics}

This theme provides insight into the role of the chair in managing board debate, dynamics and contribution on difficult tension-generating topics. Engaged non-executives, with a variety of sources of information on which to rely and a board agenda that reflects the points of strategic tension being experienced by the firm, are prepared for productive and challenging board debate, but still require a chairperson capable of managing the meeting effectively so that the 
tensions are actually addressed properly. Fundamental here is the chair role of creating a climate of open debate and trust where disagreement and tensions are voiced and worked through as a collective. An inclusive style of chairing that invites every board member to contribute his/her perspective is key. The chair acts as an integrator of differences about the strategic tensions by regularly summarising and concluding, and by putting back to the board questions that have been left unanswered as well as points of convergence.

\subsubsection{The role of the chair in managing board debate, dynamics and contribution}

The chairperson is the key individual managing board dynamics and contributions, thereby assuming a pivotal role in maintaining a climate of trust and openness, ensuring that tensions are fully confronted without the board losing its unity.

Chairpersons interviewed emphasised their role in harnessing board members' expertise and experience and allowing different perspectives to be debated freely inside the boardroom. One aspect of a chairperson's role is to be an integrator by summarising and concluding on board members' differing perspectives. The ability to conduct effective board meetings by means of open discussion and debate has been noted as a critical feature of a chairperson's role, and one that has a decisive impact on board effectiveness (Bailey and Peck, 2013; Garratt, 1999; McNulty et al., 2011; Pettigrew and McNulty, 1995; Roberts, McNulty and Stiles, 2005).

... when you get to chairman level, you need to do a lot more of: right - this is the issue; what do people think? And let the debate go, maybe direct the debate a little bit, pull people in, but try and let the debate happen. And then conclude and summarise and let the decision be a board decision rather than a chairman decision. (Chairperson 5)

The importance of good-quality debate that builds on board members' different experience and skills is perceived by chairpersons to be important, particularly with regard to difficult strategic items that are by their nature contentious. The chairperson's task is to ensure that board members do collide and have constructive conflict, but also to summarise and facilitate the integration of different views. The role of the chairperson is to expose tension points rather than avoid them, promoting open debate and healthy levels of cognitive conflict. One chairperson explained his view:

... these are the situations where there's lots of issues and lots of judgements to be made. And a good board should be one that can debate those issues openly and can manage argument successfully. The job of the chairman is making sure that 
issues come on the table and people do collide. Now it, you would love to think the board will be as one, there will be no conflict, but actually there are issues-discuss them, otherwise you will make a wrong judgement. But the executive team need that supportive guidance, and that doesn't just mean saying yes. (Chairperson 1)

Some CEOs expressed agreement on this point:

Now, some boards, I think, either don't want to talk about things which are not real and some executives don't want to talk about scary stuff that could be very dangerous. You need to get rid of both of those aspects and those discussions have to happen. (CEO 7)

In line with previous findings, it is up to the chairperson to act as a "conductor", manage dissent, and work towards a common consensual view, setting the tone on governance matters (Leblanc, 2004). Such a key requirement requires the role incumbent to be acutely aware of the board climate, sensing changes in mood, and understanding changing dynamics (Kakabadse et al., 2001).

Time and again, chairpersons interviewed emphasised the need for tension-generating topics to be fully discussed while ensuring that boardroom conflict remains constructive. It is up to the chairperson to ensure that all non-executives have their say in order to maximise the knowledge and skills of all the board, to bring in different perspectives, and to ensure collective engagement and accountability.

\begin{abstract}
It doesn't mean that you should never have disagreement in the boardroom, no, but you should be careful: you should dose it because it can become a vote of nonconfidence vis-à-vis an individual. The challenge for a chairman has to make sure that touchy items become a topic and not an item from the CEO. On the next board meeting we have two what I call topics, and everybody can there say draw a line or raise a flag because it's a topic. It's different versus if the CEO would say, "This is what I want to do", because then you have to say no to the CEO or yes to the CEO. But here it's brought as to "this is a topic" and everybody just, you have a guided discussion ... During the board meetings you make sure as a chairman that everybody has his/her point of view because you have different characters. You have some people that are very talkative. There are some people they are just saying nothing, but once they say something it's dot on. But try to make sure that at the end of an important discussion that you go round the table and ask each member their view, so they can't hide by saying nothing. (Chairperson 8)
\end{abstract}

Boards that are unable to cultivate open debate or challenge regarding tension-generating topics are seen by interviewees as dysfunctional and unable to cope with decisions about strategic tensions when they become due. One chairperson, new to the firm, explained how, during a board dinner, he questioned executives openly and challenged their answers, which 
came as a shock as this had not been a practice of the previous incumbent. In fact, this firm had severe financial and competition problems and ended up bankrupt despite the chairperson's efforts.

And, indeed, when we went to the management in the US for the first time as a board, and I did a board dinner the night before and I chaired the conversation then. I went round and questioned every executive from the US management team in front of everyone else. That had never happened before. Apparently, they were quite taken aback by that: the process and the detail of the questions. And having the pushback on the answers. (Chairperson 7)

One highly experienced chairperson made the case for open and frequent boardroom debate and challenge on important strategic issues, as well as the chairperson's role in setting the tone for the discussions:

... the board that is incapable of having debate or, if it's a very frequent thing, you'll find that lots of boards don't want, and the chairman will intervene when people start arguing and they'll close it out, take it outside the meeting. But that board is going to be tested when you get into this moment of challenges and, because it's not capable of facing into the issues, will fail. No, but the point is to have that debate. If you have argument in a board, you have to have security in the board, security meaning people; there's embedded trust and respect, and "I think your contribution is worthwhile; you think my contribution's worthwhile", so we'll listen to each other, express our views clearly, listen clearly and not think this is somehow a career-threatening, life-threatening event to have a difference of view. (Chairperson 1)

When boards are able to discuss strategic issues freely, and constructive challenge is part of the board's culture, the company benefits from different perspectives, which make for a better-informed strategy by avoiding the dominance of one particular view.

One chairperson described a situation in which the contribution of all members was important in reaching a consensus about the company's competitive advantage in a situation of restructuring and technology disruption. He described how the CEO's vision was to move the business entirely into the digital space, whereas the contribution of other board members provided a counterpoint, favouring the retention of a physical presence in stores.

The CEO's vision would probably in its more extreme be initially through a storeless society with massive online booking without an airplane and maybe even without a product. Really the magic intermediate. And [executive A] would then say, "Hey, but if you don't have a product in this kind of industry, you're not going to have anything. You need product." And that brought in the focus of product. The CFO brought in the element of finance in terms of, "Hey, but your airline isn't all that bad. It eats a lot of capital, but at the same time if we are moving into a sale 
and leaseback, it really can bring some capital in there." So they're, those are examples where you have a discussion. (Chairperson 8)

In contrast, one CEO (who viewed his chairperson as ineffective) explained how he feels boards are unprepared to deal with major tensions where solutions are not obvious and tradeoffs are required. Lack of time to reflect on tensions and a tendency for boards to prefer quick solutions were described as impeding boards' contribution to difficult strategic tensions. In such boards, he asserted, loud voices and personality often drive decisions.

\begin{abstract}
Boards tend to like to find solutions to problems. Where they struggle is where there is no solution to be found. And where you, where you've got to make a tradeoff and your personal trade-off is driven by your value set, and my personal tradeoff is driven by my value set, and somebody's got to make a decision in that. Those are difficult and they simply don't have the time to really reflect on the trade-offs, the different perspectives, and quite often, too often, the decision is influenced by personality and loud speaking. People who shout and are passionate about it. (CEO 2)
\end{abstract}

He continued by describing the boardroom environment during board meetings:

Board meetings weren't as challenging as they might be. We weren't getting the benefit of the non-execs' experience. They weren't coming forward with, "Have you thought about doing this?" "Perhaps if we did that?" or "I've been listening to a stakeholder and they think a little bit more of this, a little bit less of that" type stuff. So it was quite a passive board. It really didn't engender any real dialogue in collective problem solving. (CEO 2)

The role of the chair in fostering engagement and debate around strategic tensions is intimately linked to the incumbent's inclination regarding the desirable degree of board involvement in strategy development. The implications of this are discussed in the next section.

\title{
4.3 Implications of the degree of board involvement in strategy development
}

Among the factors determining the degree of board involvement in strategy, and which also emerge in this study, are: the extent to which the chairperson actually wants the board involved in strategy (O'Neal and Thomas, 1995); board meeting agendas; the processes and conduct of meetings; and the role of away-days or informal dialogue between the board and the executives (McNulty and Pettigrew, 1999). Previous literature has portrayed board involvement in strategy as a passive-active continuum (e.g. Demb and Neubauer, 1992; Hendry, Kiel and Nicholson, 2010; Zahra, 1990). Scholars advancing the idea of this 
continuum have found that UK boards play an active role in strategy, challenging managerial perspectives, especially in times of crisis or poor performance (McNulty and Pettigrew, 1999; Stiles and Taylor, 1996, 2001; Westphal and Fredrickson, 2001), and chairpersons' accounts in the present study suggest this is the case. Insofar as directors draw on their knowledge, experience and skills to influence management and shape strategy, they assume the role of resource providers (McNulty and Pettigrew, 1999). However, we challenge this idea of the passive-active continuum, in that it "assumes linearity in the strategy process, but strategic decisions often evolve through complex, non-linear and fragmented processes" (Hendry, Kiel and Nicholson, 2010:35). Those chairperson accounts in this study that indicate that board meetings require the board to adopt an active and challenging position with regard to tensiongenerating topics and management proposals imply that, in fact, strategy more resembles a highly contextual, interactive and complex practice where active and passive behaviours coexist (Carter and Lorsch, 2004). Boards participate in strategy by continuously interacting with management and other stakeholders (Jensen and Zajac, 2004; Useem and Zelleke, 2006).

Recent research on "strategy as practice" has found that boards focus more on "interactive strategising" (as opposed to procedural strategising) involving "direct face-to-face interaction between senior management and other organisational actors in order to influence the development and execution of strategy" (Hendry, Kiel and Nicholson, 2010:37). Such strategising practice is seen as an "interpretative practice" which enables "top managers to argue for their own interpretations of strategy" relying on "social exchanges in which individuals and groups communicate, persuade, negotiate (and re-negotiate), continuously building shared frameworks of meaning about strategy in order to influence each other's behaviors" (Hendry, Kiel and Nicholson, 2010:37). Importantly, such interactive strategising is likely to be used when the board's strategic stance favours a change in strategic direction, typically when the firm finds itself in an environment characterised by complexity and resource scarcity. The chairperson's chosen type of engagement and debate critically determines the degree of board involvement and influence over the firm's strategy.

\section{Conclusion}

This chapter has presented evidence of the discretionary choices the chair possesses in looking to harness the effectiveness of the board in order to deal with strategic tensions. Such choices 
primarily revolve around board engagement and practices of debate. Skilful use of such practices can be a means of handling difficult tension-generating challenges effectively and in a systematic way. These practices include setting and developing engagement policy and practice such that non-executive directors (NEDs) engage with the business by talking to people at different levels within the company, and by visiting operations and attending specific events. This offers NEDs unfiltered information and insight about the firm, impossible to obtain merely sitting around the boardroom table. It also means that board-CEO engagement is characterised by trust and members are comfortable with raising and discussing difficult issues. Early engagement with tension-generating topics allows NEDs to track management thinking and provide input before too much commitment has been made by the executive. This avoids frustration on either side, and allows more time for reflection on potentially contentious issues, leading to a much more supportive form of engagement between the board and the executive.

Another important chairperson practice is mobilising the whole board to engage in committee work: every NED might therefore sit on a committee, even though he or she may not be a voting member of the board. In this way, all board members can maintain the same level of information. Finally, relevant strategic tensions and challenges need to be addressed proactively. A high-performing chair identifies (via NEDs and the executive) strategic tensions and ensures the board agenda reflects them. But encouraging engagement requires of the chair strong skills in conducting board meetings. Evidence suggests that high-performing chairs have an inclusive style, drawing all members into the discussion and ensuring that tensions are fully confronted and illuminated from multiple perspectives. The chair also emerges as an integrator of tensions by regularly summarising the different perspectives and building a shared understanding among board members, thereby maintaining board unity.

These findings challenge those conceptions that see board involvement in strategy as belonging to a passive-active continuum; instead, they suggest that a high-performing chair creates engaged and informed boards capable of being meaningfully involved in scrutinising and developing the firm's strategy.

Most chairs assume their position without any prior training or understanding of what being a chairperson really means. They are supposed to "just know" how to lead the board. This study suggests that leading the board requires skills and preparation especially in the area of managing engagement and practice debate, which are the most critical in ensuring boards discharge their duties appropriately. This study therefore proposes that regulators in the UK and elsewhere provide more guidance and examples of best practice for chairs as regards how to promote adequate levels of engagement and debate around the right topics - i.e. those that 
involve strategic tensions. To monitor and/or benchmark such practices, it is proposed that levels of engagement and debate might be voluntarily disclosed by boards, along with initiatives that have been taken to strengthen these practices, such as chair development, NED visits to operations, NED-only meetings, and so on. 


\section{References}

Bailey, B. C. and Peck, S. I. (2013), 'Boardroom strategic decision-making style: Understanding the antecedents', Corporate Governance: An International Review, 21(2), 131-146.

Boyden, R. (2014), 'The past, present and future of the board', Management Today, March, $40-44$.

Braun, V. and Clarke, V. (2006), 'Using thematic analysis in psychology', Qualitative Research in Psychology, 3(2), 77-101.

Cadbury Committee Report (1992), Report on the financial aspects of corporate governance, London: Gee Publishing.

Carter, Colin and Lorsch, Jay (2004), Back to the drawing board: Designing corporate boards for a complex world, Boston, MA: Harvard Business School Press.

Davies, E. M. (2015), 'Improving the gender balance on British boards', accessed 16 March 2016,https://www.gov.uk/government/uploads/system/uploads/attachment_data/file/48 2059/BIS-15-585-women-on-boards-davies-review-5-year-summary-october-2015.pdf.

Demb, Ada and Neubauer, F.-Friedrich (1992), The corporate board: Confronting the paradoxes, Oxford, UK: Oxford University Press.

Dulewicz, V., Gay, K. and Taylor, B. (2007), 'What makes an outstanding chairperson? Findings from the UK Non-Executive Director of the Year Awards 2006', Corporate Governance: An International Review, 15(6), 1,056-1,069.

Financial Reporting Council (2016), The UK Corporate Governance Code, accessed 20 December 2016, https://www.frc.org.uk/Our-Work/Publications/CorporateGovernance/Final-Draft-UK-Corporate-Governance-Code-2016.pdf.

Francis, J. J., Johnston, M., Robertson, C., Glidewell, L., Entwistle, V., Eccles, M. P. and Grimshaw, J. M. (2010), 'What is an adequate sample size? Operationalising data saturation for theory-based interview studies', Psychology and Health, 25(10), 1,2291,245 .

Gabrielsson, J., Huse, M. and Minichilli, A. (2007), 'Understanding the leadership role of the board chairperson through a team production approach', International Journal of Leadership Studies, 3(1), 21-29.

Garratt, B. (1999), 'Developing effective directors and building dynamic boards', Long Range Planning, 32(1): 28-35. 
Hales, C. P. (1986). What do managers do? A critical review of the evidence, Journal of Management Studies, 23(1): 88-115.

Harrison, J. R. (1987), 'The strategic use of corporate board committees', California Management Review, 30(1), 109-125.

Hendry, K. P., Kiel, G. C. and Nicholson, G. (2010), 'How boards strategise: A strategy as practice view', Long Range Planning, 43(1), 33-56.

Jensen, M. C. and Zajac, E. J. (2004), 'Corporate elites and corporate strategy: How demographic preferences and structural position shape the scope of the firm', Strategic Management Journal, 25(6), 507-524.

Kakabadse, A. P. and Kakabadse, N. K. (2007a), 'The return of the chairman', Business Strategy Review, 18(4), 62-65.

Kakabadse, N. K. and Kakabadse, A. P. (2007b), 'Chairman of the board: Demographics effects on role pursuit', Journal of Management Development, 26(2), 169-192.

Kakabadse, Andrew and Kakabadse, Nada (2008), Leading the board: The six disciplines of world-class chairperson, London: Palgrave.

Kakabadse, A. P., Kakabadse, N. K. and Barratt, R. (2006), 'Chairman and chief executive officer (CEO): That sacred and secret relationship', Journal of Management Development, 25(2), 134-150.

Kakabadse, A., Ward, K., Kakabadse, N., and Bowman, C. (2001), 'Role and contribution of non-executive directors', Corporate Governance: The International Journal of Effective Board Performance, 1(1), 4-7.

Kakabadse, A. P., Kakabadse, N. K. and Knyght, R. (2010), "The "chemistry factor" in the chairman/CEO relationship', European Management Journal, 28(4), 285-296.

Kroeck, K. G. (2003), 'Rosemary Stewart on management: Behavioral scribe, squire of theory, pragmatic scientist', The Leadership Quarterly, 14(2), 204-216.

Leblanc, R. W. (2004), 'What's wrong with corporate governance: A note', Corporate Governance: An International Review, 12(4), 436-441.

Leblanc, Richard and Gillies, James (2005), Inside the boardroom: How boards really work and the coming revolution in corporate governance, Ontario: John Wiley \& Sons.

Levrau, A. and Van den Berghe, L. (2013), 'Perspectives on the decision-making style of the board chair'. International Journal of Disclosure and Governance, 10(2), 105-121.

McCabe, M. and Nowak, M. (2008), 'The independent director on the board of company directors', Managerial Auditing Journal, 23(6), 545-566. 
McNulty, T., and Pettigrew, A. (1999), 'Strategists on the board', Organization Studies, 20(1), $47-74$.

McNulty, T., Pettigrew, A., Jobome, G. and Morris, C. (2011), 'The role, power and influence of company chairs', Journal of Management and Governance, 15(1), 1-121.

Morais, F. (2017), Chairperson and CEO roles responses to strategic tensions: a UK-based study, Doctoral Thesis, University of Reading, UK.

Morais, F., Kakabadse, A., and Kakabadse, N. (2018), 'The chairperson and CEO roles interaction and responses to strategic tensions', Corporate Governance: The International Journal of Business in Society, 18(1), 143-164.

O’Neal, D. and Thomas, H. (1995), 'Director networks/director selection: The board's strategic role', European Management Journal, 13(1), 79-90.

Parry, K. W. (2003), 'Of complexity and distillation: Stewart's contribution to understanding what managers really do', The Leadership Quarterly, 14(2), 216-221.

Patton, Michael (2002), Qualitative research and evaluation methods (3rd ed.), Thousand Oaks, CA: Sage.

Pettigrew, A. and McNulty, T. (1995), 'Power and influence in and around the boardroom', Human Relations, 48(8), 845-873.

Roberts, J. (2002), 'Building the complementary board. The work of the Plc chairman', Long Range Planning, 35(5), 493-520.

Roberts, J., McNulty, T. and Stiles, P. (2005), 'Beyond agency conceptions of the work of the non-executive director: Creating accountability in the boardroom', British Journal of Management, 16(S1), S5-S26.

Saunders, Mark, Lewis, Philip, and Thornhill, Adrian (2009), Research methods for business students (5th ed.), London: FT Prentice Hall.

Sharpe, N. (2012), 'Process over structure: An organizational behavior approach to improving corporate boards', Southern California Law Review, 85, 261-311.

Spencer Stuart. (2017a), 'US Board Index', accessed 15 May 2018, https://www.spencerstuart.com/-

/media/ssbi2017/ssbi_2017_final.pdf?la=en\&hash=DADA958C9B4F21467A69938F F1C44D490AB93D58.

Spencer Stuart (2017b), 'UK Board Index', accessed 15 May 2018, https://www.spencerstuart.com/ /media/pdf\%20files/research\%20and\%20insight $\% 20$ pdfs/ukbi2017_b.pdf. 
Spira, L. F. and Bender, R. (2004), 'Compare and contrast: Perspectives on board committees', Corporate Governance: An International Review, 12(4), 489-499.

Stewart, R. 1982, 'A model for understanding managerial jobs and behavior', Academy of Management Review, 7(1), 7-13.

Stewart, R. 1991, 'Chairperson and chief executives: An exploration of their relationship', Journal of Management Studies, 28(5), 511-527.

Stewart, R. (2003), 'Woman in a man's world', The Leadership Quarterly, 14(2), 197-204.

Stiles, P. and Taylor, B. (1996), 'The strategic role of the board', Corporate Governance: An International Review, 4(1), 3-10.

Stiles, Philip and Taylor, Bernard (2001), Boards at work: How directors view their roles and responsibilities, Oxford, UK: Oxford University Press.

Taylor, B. (2001), 'From corporate governance to corporate entrepreneurship'. Journal of Change Management, 28(2), 128-147.

Useem, M. and Zelleke, A. (2006), 'Oversight and delegation in corporate governance: Deciding what the board should decide', Corporate Governance: An International Review, 14(1), 2-12.

Westphal, J. D. and Fredrickson, J. W. (2001), 'Who directs strategic change? Director experience, the selection of new CEOs, and change in corporate strategy', Strategic Management Journal, 22 (1), 1113-1,137.

Withers, M.C. and Fitza, M.A. (2017), 'Do board chairs matter? The influence of board chairs on firm performance', Strategic Management Journal, 38(6), 1343-1355.

Zahra, S. (1990), 'Increasing the board's involvement in strategy', Long Range Planning, 23(6), 109-117. 